\title{
A review of side-effects experienced by patients taking clofazimine
}

\author{
VICTORIA J MOORE* \\ 23 Colebourne Road, King's Heath, Birmingham B13 OEZ
}

Accepted for publication 5 May 1983

Summary The incidence of specific side-effects experienced by 65 patients taking clofazimine was assessed. All but one had suffered side-effects; skin and conjunctival pigmentation being the commonest. Abdominal pain was a complaint in one-third of the patients.

The 57 patients who were still taking clofazimine were divided into 2 groups according to dosage. The incidence of side-effects was similar in both groups. The average times of onset of the side-effects since starting clofazimine, in all instances, were greater in the lower dosage group. The possible significance of this is discussed.

Eight patients who had discontinued clofazimine therapy were seen. The disappearance of the side-effects was, in the majority of cases, 6 months or more after stopping therapy.

The difficulties associated with assessing dimness of vision and time intervals retrospectively were discussed.

No patients had stopped clofazimine due to side-effects. Five patients expressed dislike of the side-effects, 3 of which were in the lower dosage group. One patient asked for an increase in dosage to control an ENL reaction. The tolerance of side-effects, in general, was very good.

No patients suffered serious adverse reactions.

\section{Introduction}

Clofazimine is a substituted phenazine ${ }^{1}$ which is active against Mycobacteria. It has been used in the treatment of leprosy for more than 10 years, both for its anti-mycobacterial effect and at relatively high doses to suppress moderate to severe erythema nodosum leprosum (ENL).

Clofazimine is highly lipophilic and tends to be deposited in fatty tissue and cells of the reticulo-endothelial system..$^{2}$ It has a tendency to remain in human tissue a long time, its half-life being at least 70 days. $^{3}$

* Elective Student, Schieffelin Leprosy Training and Research Centre, Karigiri, Tamil Nadu, Southern India. 
A very large number of papers have been published on the side-effects of clofazimine and have been reviewed. ${ }^{4}$ Several workers have found potentially serious side-effects relating to the GI tract, ${ }^{5-8}$ histopathological evidence of widespread clofazimine crystal deposition being found in some studies. ${ }^{9}$

The aim of this study is to obtain firm figures of the incidence of side-effects related to dose and duration of treatment, their subsidence after withdrawal and to assess the patients' tolerance of these.

\section{Material and methods}

All patients currently taking clofazimine and a few who had previously taken it, who attended Schieffelin Leprosy Training and Research Centre, out-patients or village clinics were interviewed with specific questions about anticipated side-effects.

The side-effects were considered in 3 sections: skin, eye and gastrointestinal tract. An estimate of the time relation of taking clofazimine and the onset of side-effects was obtained.

The patients were divided into 3 groups: those taking up to $700 \mathrm{mg} /$ week as anti-mycobacterial therapy (group A), those taking higher doses for anti-inflammatory effect (group B) and those who had discontinued clofazimine treatment (group C). Capsules (100 mg) were taken after meals and in groups B and C, in divided doses.

Thirty-four patients taking clofazimine at a dose of $700 \mathrm{mg}$ or less per week were seen (group A), the duration of treatment ranging from 1 to 83 months.

Twenty-three patients on higher doses averaged 10.5 months of treatment (group B); the maximum dose of $300 \mathrm{mg}$ daily being given 3.1 months on average (with a maximum of 9 months). Four of the 23 patients had never received a dose of more than $200 \mathrm{mg}$ daily.

The 8 patients seen who had had clofazimine previously for its anti-inflammatory effect, averaged $16 \cdot 8$ months of treatment, with a maximum number of 11 months at $300 \mathrm{mg}$ daily (averaging 4.4 months at this dose).

\section{Presentation of results}

Tables 1-3 show the results in each group. They show the numbers and percentages of patients suffering the named side-effect, the times of onset since starting clofazimine and in the case of group $\mathrm{C}$, the times of disappearance of the side-effect after stopping clofazimine.

Only one patient did not complain of any side-effects, having had $100 \mathrm{mg}$ daily for 1 month. The average number of complaints per patient was 2.7 in the low dosage group, $2 \cdot 8$ in the higher dosage group and 3.0 in group $\mathrm{C}$. 
Table 1. 'Skin' side-effects of clofazimine in patients from groups A-C

\begin{tabular}{|c|c|c|c|c|}
\hline & Discoloration & Pigmentation & Dryness & Other \\
\hline \multicolumn{5}{|l|}{ Group A (34) } \\
\hline $\begin{array}{l}\text { Number (and } \\
\text { percentage) }\end{array}$ & $\begin{array}{c}8 \\
(23 \cdot 5 \%)\end{array}$ & $\begin{array}{c}18 \\
(52 \cdot 9 \%)\end{array}$ & $\begin{array}{c}12 \\
(35 \cdot 3 \%)\end{array}$ & $\begin{array}{c}1 \\
(2 \cdot 9 \%) \\
\text { (a complaint of } \\
\text { generalized pruritus) }\end{array}$ \\
\hline $\begin{array}{l}\text { Average times } \\
\text { (and ranges) }\end{array}$ & $\begin{array}{l}3.5 \text { months } \\
\text { (immediately- } \\
8 \text { months) }\end{array}$ & $\begin{array}{l}2 \cdot 5 \text { months } \\
\text { (immediately- } \\
6 \text { months) }\end{array}$ & $\begin{array}{l}4 \text { months } \\
\text { (immediately- } \\
10 \text { months) }\end{array}$ & - \\
\hline \multicolumn{5}{|l|}{ Group B (23) } \\
\hline $\begin{array}{l}\text { Number (and } \\
\text { percentage) }\end{array}$ & $\begin{array}{c}4 \\
(17 \cdot 4 \%)\end{array}$ & $\begin{array}{c}17 \\
(73 \cdot 9 \%)\end{array}$ & $\begin{array}{c}8 \\
(34 \cdot 8 \%)\end{array}$ & $\begin{array}{c}2 \\
(8 \cdot 7 \%) \\
\text { (two cases of } \\
\text { generalized pruritus) }\end{array}$ \\
\hline $\begin{array}{l}\text { Average times } \\
\text { (and ranges) }\end{array}$ & $\begin{array}{l}1 \text { month } \\
\text { (immediately- } \\
3 \text { months) }\end{array}$ & $\begin{array}{c}3 \text { weeks } \\
\text { (immediately- } \\
3 \text { to } 4 \text { months) }\end{array}$ & $\begin{array}{c}5 \text { weeks } \\
\text { ( } 1 \text { month- } \\
3 \text { to } 4 \text { months) }\end{array}$ & $\begin{array}{l}\text { (1 month and } \\
5 \text { months) }\end{array}$ \\
\hline \multicolumn{5}{|l|}{ Group C (8) } \\
\hline $\begin{array}{l}\text { Number (and } \\
\text { percentage) }\end{array}$ & $\begin{array}{c}1 \\
(12 \cdot 5 \%)\end{array}$ & $\begin{array}{c}7 \\
(87 \cdot 5 \%)\end{array}$ & $\begin{array}{c}3 \\
(37 \cdot 5 \%)\end{array}$ & $\underline{0}$ \\
\hline $\begin{array}{l}\text { Average times } \\
\text { (and ranges) }\end{array}$ & (5-6 months) & $\begin{array}{l}4.2 \text { months } \\
\text { ( } 1 \text { week- } \\
2 \text { months })\end{array}$ & $\begin{array}{l}\text { (1 month and } \\
3 \text { months) }\end{array}$ & - \\
\hline $\begin{array}{l}\text { Times of } \\
\text { disappearance }\end{array}$ & (3 months) & $\begin{array}{c}8 \text { months } \\
\text { (6 months- } \\
1 \text { year) } \\
\text { (One patient } \\
\text { is still pigmented } \\
4 \text { months after } \\
\text { stopping } \\
\text { clofazimine) }\end{array}$ & $\begin{array}{l}8 \text { months } \\
\text { (in } 2 \text { cases } \\
\text { dryness is } \\
\text { still present } \\
1 \text { year and } 3 \\
\text { years since } \\
\text { stopping } \\
\text { clofazimine) }\end{array}$ & - \\
\hline
\end{tabular}

Table 4 shows the percentage of patients complaining of each side-effect, in total and in each group.

\section{Discussion of results}

The most common side-effect was skin pigmentation and conjunctival pigmentation, being complained of by $64 \cdot 6 \%$ and $49 \cdot 2 \%$ of all patients respectively. Abdominal pain was a complaint of just over one-third of all patients. 
Table 2. Ocular side-effects of clofazimine in patients from groups $\mathrm{A}-\mathrm{C}$

\begin{tabular}{|c|c|c|c|c|}
\hline & $\begin{array}{l}\text { Conjunctival } \\
\text { pigmentation }\end{array}$ & $\begin{array}{l}\text { Dimness of } \\
\text { vision }\end{array}$ & Dryness & Other \\
\hline \multicolumn{5}{|l|}{ Group A (34) } \\
\hline $\begin{array}{l}\text { Number (and } \\
\text { percentage) }\end{array}$ & $\begin{array}{c}16 \\
(47 \cdot 1 \%)\end{array}$ & $\begin{array}{c}7 \\
(20 \cdot 6 \%)\end{array}$ & $\underline{0}$ & $\begin{array}{c}11 \\
(32 \cdot 4 \%) \\
\text { (various complaints } \\
\text { including burning (4) } \\
\text { itching (4), irritation }(2) \\
\text { and pricking (1) of the eyes) }\end{array}$ \\
\hline $\begin{array}{l}\text { Average times } \\
\text { (and ranges) }\end{array}$ & $\begin{array}{c}3 \text { months } \\
\text { (immediately- } \\
1 \text { year) }\end{array}$ & $\begin{array}{l}11 \text { months } \\
\text { (immediately- } \\
30 \text { months) }\end{array}$ & - & $\begin{array}{l}7 \cdot 5 \text { months } \\
(3 \text { months- } \\
22 \text { months })\end{array}$ \\
\hline \multicolumn{5}{|l|}{ Group B (23) } \\
\hline $\begin{array}{l}\text { Number (and } \\
\text { percentage) }\end{array}$ & $\begin{array}{c}13 \\
(56 \cdot 5 \%)\end{array}$ & $\begin{array}{c}1 \\
(4 \cdot 3 \%)\end{array}$ & $\begin{array}{c}1 \\
(4 \cdot 3 \%)\end{array}$ & $\begin{array}{c}3 \\
\left(13 \cdot 0^{\circ}\right) \\
\text { (burning, irritation } \\
\text { and watering) }\end{array}$ \\
\hline $\begin{array}{l}\text { Average times } \\
\text { (and ranges) }\end{array}$ & 3 weeks & (1 month) & - & - \\
\hline \multicolumn{5}{|l|}{ Group C (8) } \\
\hline $\begin{array}{l}\text { Number (and } \\
\text { percentage) }\end{array}$ & $\begin{array}{c}3 \\
(37 \cdot 5 \%)\end{array}$ & $\underline{0}$ & $\underline{0}$ & $\begin{array}{c}1 \\
(12 \cdot 5 \%) \\
\text { (prescription of } \\
\text { eye drops once only) }\end{array}$ \\
\hline $\begin{array}{l}\text { Times of } \\
\text { appearance of } \\
\text { side-effects }\end{array}$ & $\begin{array}{l}\text { (1 month, } 1 \\
\text { month and } 2 \\
\text { months) }\end{array}$ & - & - & (7 months) \\
\hline $\begin{array}{l}\text { Times of } \\
\text { disappearance of } \\
\text { side-effects }\end{array}$ & $\begin{array}{l}3 \text { months } \\
\text { ( } 2 \text { patients } \\
\text { still have } \\
\text { pigmentation } \\
15 \text { and } 4 \\
\text { months after } \\
\text { stopping) }\end{array}$ & - & - & (one prescription) \\
\hline
\end{tabular}

In general both groups $\mathrm{A}$ and $\mathrm{B}$ have similar incidences of side-effects. In view of the small numbers involved in the study no formal evaluation of significance of differences has been performed. Some side-effects in group $\mathrm{C}$ were inferred from the records of drug therapy.

The percentage of patients complaining of skin colour changes (pigmentation and/or discoloration) was very similar in groups A and B. One patient in group A 
Table 3. Gastro-intestinal side-effects of clofazimine

\begin{tabular}{|c|c|c|c|c|}
\hline & Abdominal pain & Nausea & Diarrhoea & Other \\
\hline \multicolumn{5}{|l|}{ Group A (34) } \\
\hline $\begin{array}{l}\text { Number (and } \\
\text { percentage) }\end{array}$ & $\begin{array}{c}10 \\
(29 \cdot 4 \%)\end{array}$ & $\begin{array}{c}3 \\
(8 \cdot 8 \%)\end{array}$ & $\begin{array}{c}1 \\
(2 \cdot 9 \%)\end{array}$ & $\begin{array}{c}6 \\
(17 \cdot 6 \%) \\
\text { (weight loss (2), 'no } \\
\text { digestive power' (2), } \\
\text { blood in stools (1) and } \\
\text { vomiting, } 4 \text { bouts (1)) }\end{array}$ \\
\hline $\begin{array}{l}\text { Average times } \\
\text { (and ranges) }\end{array}$ & $\begin{array}{l}6.5 \text { months } \\
\text { (immediately- } \\
16 \text { months) }\end{array}$ & $\begin{array}{l}\text { (immediately } \\
\text { and } 7 \text { months) }\end{array}$ & - & $\begin{array}{c}(3,3,5,10 \text { and } 18 \\
\text { months })\end{array}$ \\
\hline \multicolumn{5}{|l|}{ Group B (23) } \\
\hline $\begin{array}{l}\text { Number (and } \\
\text { percentage) }\end{array}$ & $\begin{array}{c}8 \\
(34 \cdot 8 \%)\end{array}$ & $\begin{array}{c}1 \\
(4 \cdot 3 \%)\end{array}$ & $\begin{array}{c}4 \\
(17 \cdot 4 \%)\end{array}$ & $\begin{array}{c}1 \\
(4 \cdot 3 \%) \\
\text { (appetite loss, weight } \\
\text { loss and one bout of } \\
\text { vomiting-one patient) }\end{array}$ \\
\hline $\begin{array}{l}\text { Average times } \\
\text { (and ranges) }\end{array}$ & $\begin{array}{l}4.5 \text { months } \\
(1 \text { month- } \\
13 \text { months })\end{array}$ & - & $\begin{array}{l}\text { (1 month, } 2 \\
\text { months and } \\
5 \text { months })\end{array}$ & (1 week) \\
\hline \multicolumn{5}{|l|}{ Group C (8) } \\
\hline $\begin{array}{l}\text { Number (and } \\
\text { percentage) }\end{array}$ & $\begin{array}{c}4 \\
(50 \cdot 0 \%)\end{array}$ & $\begin{array}{c}2 \\
(25 \cdot 0 \%)\end{array}$ & $\begin{array}{c}1 \\
(12 \cdot 5 \%)\end{array}$ & $\begin{array}{c}2 \\
(25 \cdot 0 \%) \\
\text { (vomiting }-4 \text { bouts }(1), \\
\text { nausea, vomiting and } \\
\text { weight loss }(1))\end{array}$ \\
\hline $\begin{array}{l}\text { Times of } \\
\text { appearance of } \\
\text { side-effects }\end{array}$ & $\begin{array}{c}(2 \text { months, } 2 \\
\text { months and } \\
11 \text { months })\end{array}$ & $\begin{array}{l}\text { (immediately } \\
\text { and } 2 \text { months) }\end{array}$ & (immediately) & (2 weeks) \\
\hline $\begin{array}{l}\text { Times of } \\
\text { disappearance } \\
\text { of side-effects }\end{array}$ & $\begin{array}{c}2 \text { years } \\
\text { (2 patients } \\
\text { are still } \\
\text { complaining } 1 \\
\text { year and } 1 \frac{1}{2} \\
\text { years after } \\
\text { stopping } \\
\text { clofazimine) }\end{array}$ & $\begin{array}{l}\text { ( } 2 \text { months and } \\
2-3 \text { months } \\
\text { after } \\
\text { starting } \\
\text { clofazimine) }\end{array}$ & $\begin{array}{l}\text { (a few days } \\
\text { after starting } \\
\text { clofazimine) }\end{array}$ & - \\
\hline
\end{tabular}

Note. Averages were not calculated for four or less values. In such cases the reported times are given in parentheses. 
Table 4. Percentage of patients complaining of each side-effect

\begin{tabular}{|c|c|c|c|c|c|c|c|c|c|c|c|c|}
\hline & \multicolumn{4}{|c|}{ Skin } & \multicolumn{4}{|c|}{ Eye } & \multicolumn{4}{|c|}{ GIT } \\
\hline & Disc. & Pigm. & Dry & Other & $\begin{array}{l}\text { Conj. } \\
\text { Pigm. }\end{array}$ & $\begin{array}{l}\text { Dim. } \\
\text { vision }\end{array}$ & Dry & Other & $\begin{array}{l}\text { Abdo } \\
\text { pain }\end{array}$ & Nausea & Diarrh. & Other \\
\hline \multirow[t]{2}{*}{ Group A } & $23 \cdot 5 \%$ & $52 \cdot 9 \%$ & $35 \cdot 3 \%$ & $2 \cdot 9 \%$ & $47 \cdot 1 \%$ & $20 \cdot 6 \%$ & 0 & $32 \cdot 4 \%$ & $29 \cdot 4 \%$ & $8.8 \%$ & $2 \cdot 9 \%$ & $17 \cdot 6 \%$ \\
\hline & \multicolumn{2}{|c|}{$73 \cdot 5 \%$} & \multicolumn{10}{|c|}{$32 \cdot 4 \%$} \\
\hline \multirow[t]{2}{*}{ Group B } & $17 \cdot 4 \%$ & $73.9 \%$ & $34 \cdot 8 \%$ & $8.7 \%$ & $56 \cdot 5 \%$ & $4 \cdot 3 \%$ & $4.3 \%$ & $13 \cdot 0 \%$ & $34 \cdot 8 \%$ & $4 \cdot 3 \%$ & $17 \cdot 4 \%$ & $4 \cdot 3 \%$ \\
\hline & \multicolumn{2}{|c|}{$78 \cdot 3 \%$} & \multirow{3}{*}{$(37 \cdot 5 \%)$} & \multirow{3}{*}{0} & \multirow{3}{*}{$(37 \cdot 5 \%)$} & \multirow{3}{*}{0} & \multicolumn{2}{|c|}{$17 \cdot 4 \%$} & & & & \\
\hline \multirow[t]{2}{*}{ Group C } & $(12.5 \%)$ & $(87.5 \%)$ & & & & & 0 & $(12 \cdot 5 \%)$ & $(50 \cdot 0 \%)$ & $(25 \cdot 0 \%)$ & $(12 \cdot 5 \%)$ & $(25 \cdot 0 \%)$ \\
\hline & \multicolumn{2}{|c|}{$(100 \%)$} & & & & & \multicolumn{2}{|c|}{$(12 \cdot 5 \%)$} & & & & \\
\hline All patients & $20.0 \%$ & $64 \cdot 6 \%$ & $35.4 \%$ & $4.6 \%$ & $49 \cdot 2 \%$ & $12 \cdot 3 \%$ & $1.5 \%$ & $23 \cdot 1 \%$ & $33 \cdot 8 \%$ & $9 \cdot 2 \%$ & $9 \cdot 2 \%$ & $16.9 \%$ \\
\hline
\end{tabular}


and 3 in group B complained of both discoloration and pigmentation, in all cases redness preceded pigmentation. There were two cases of obvious discoloration and one of pigmentation in the low dosage group which were not complained of; they were not included in the tables. Sometimes pigmentation was only in patches (in reaction spots or sites of nodules). The average time between emergence of skin colour changes and taking clofazimine was noticeably less in the higher dosage group.

All patients in group C noted skin colour changes: pigmentation occurring on average 1 month after starting treatment. (This is similar to the average of 3 weeks noted by patients still taking clofazimine for its anti-inflammatory effect.) The pigmentation disappeared 8.5 months (on average) after stopping the drug - the maximum being 1 year.

Dry skin was a complaint of $30 \%$ of patients in both groups. Average times before the onset of these symptoms were considerably shorter in the higher dosage group. One case of dryness (in group C) was a severe fissuring dermatitis still present 3 years after stopping therapy.

Conjunctival pigmentation was complained of by $56 \cdot 6 \%$ of group B patients compared with $47 \%$ of group A; the average time before onset being 3 weeks and 3 months respectively. One patient in group B and 3 in group A had obvious pigmentation which was not complained of. Pigmentation disappeared on average 3 months after stopping treatment (group C); but one patient still has this feature 15 months after stopping clofazimine.

Complaints of dry eyes have been combined with complaints such as eye burning, itching, etc., in the percentage tables. These latter symptoms may well be a manifestation of dry eyes; they are common complaints in leprosy in general. Such complaints were found to be much more common in low dosage patients.

Dimness of vision since clofazimine treatment was also complained of much more frequently in group A. There are many difficulties associated with assessing this complaint. Several of the patients who complained of dim vision since taking clofazimine (after reviewing their ophthalmology notes) had, in fact, had dim vision before taking the drug and/or had had visual acuity checked since starting clofazimine with no change detected. These were not included in the tables. The ones that are included have had no formal eye examination to confirm their complaint.

The percentage of patients complaining of gastro-intestinal symptoms relating to the onset of clofazimine treatment was similar in both groups.

Abdominal pain was a common complaint but was never severe. One patient only had pain with initial treatment; another 4 said the pain was very mild. Two patients in group $C$ still have pain 1 year and $1 \frac{1}{2}$ years since last taking clofazimine.

Nausea was often a vague complaint. One case was only at night, another occurred once per month and often the nausea was only an occasional problem.

Diarrhoea was a relatively rare complaint. Three of the cases had only 
occurred with initial therapy (lasting a few days to 2 weeks). A fourth case was a complaint of occasional diarrhoea.

The accuracy of times stated is dubious in some cases. A few patients had difficulty remembering time relations, especially those on long-term therapy or discontinued therapy. There are many instances of patients vaguely saying a side-effect was noted immediately the drug was started; the concept of 'immediately' may vary markedly between patients. Also the concept of time in terms of weeks or months is probably foreign to many villagers. On several occasions a patient would state the same time relation for all symptoms complained of, which may indicate inaccuracy of time associations in general. However, these considerations apply to all groups and the overall differences between groups may still be valid ones.

In general the ranges of time intervals are wider in group $\mathrm{A}$. This is marked in the dimness of vision section, in which the stated time of onset after starting clofazimine varies from immediately to 30 months. Since all patients in this group (apart from one) were taking $100 \mathrm{mg}$ daily at the onset of treatment the possibility of this not being a real side-effect but an incidental occurrence is raised. The much larger percentage of patients complaining of this side-effect in the lower dosage group supports this possibility. Other explanations such as variation in absorption, metabolism and distribution of clofazimine could also explain such variations in time relations for the same side-effect in one group.

A few patients related subsidence or disappearance of side-effects with decreasing doses of clofazimine. Skin dryness, eye dryness and conjunctival and skin pigmentation were the symptoms noted to diminish.

Two patients voluntarily stated a dislike of taking clofazimine; one for no specific reason and the other (an Anglo-Indian) because of increasing skin pigmentation - the degree of pigmentation decreasing since a dose decrease. Two female patients were moderately displeased about facial discolouration when directly asked. They were in the low dosage group. Although skin colour changes were a common side-effect these were the only patients who disliked it. This may be due to the fact that Southern Indians are generally more pigmented than the Northern Indians and also lack of knowledge of the association of this side-effect and leprosy amongst the general population.

One patient, when taking $200 \mathrm{mg}$ per day, experienced another ENL reaction and asked for an increase in dosage. Several other patients (especially in group B) said they did not mind the side-effects to gain the benefits of clofazimine.

I did not find any patients who had stopped taking clofazimine due to side-effects. In general side-effects were considered easily tolerable.

\section{Acknowledgments}

The encouragement and guidance of Dr P M Taylor and the assistance of the staff 
and patients at Schieffelin Leprosy Training and Research Centre were invaluable and much appreciated. My thanks must also be extended to Dr R J W Rees and LEPRA for making the research possible. I also wish to thank Dr E P Fritschi (Director of SLT \& RC) for his advice with regard to this publication.

\section{References}

I Barry VC, Belton JG, Connalty ML, Denney JM, Edward DW, O'Sullivan JF, Twomey D, Winder F. A new series of phenazines (Rimino compounds) with high affinity anti-tuberculosis activity. Nature, 1957; 179: 1013.

2 Mansfield RE. Tissue concentrations of clofazamine (B663) in man. Amer J Trop Med Hyg, 1974; 23: 1116.

3 Levy L. Pharmacologic studies of clofazamine. Amer J Trop Med Hyg, 1974; 23: 1097.

4 Jopling WH. Complications of treatment with clofazamine (Lamprene: B663). Lepr Rev, 1976; 47: 1 .

${ }^{5}$ Mason GH, Ellis-Pegler RB, Arthur JF. Clofazamine and eosinophilic enteritis. Lepr Rev, 1972; 48: 175 .

${ }^{6}$ Ramu G, Iyer CGS. Side-effects of clofazamine therapy. Lepr India, 1976; 48: 722.

7 Plock H, Leiker DL. A long term trial with clofazamine in reactive lepromatous leprosy. Lepr Rev, 1976; 47: 25.

${ }^{8}$ Sardari Lal, Garg BR, Hameedulla A. Gastro-intestinal side-effects of clofazamine. Lepr India, 1981; 53: 2.

9 McDougall AC, Horsfall WR, Hede JE, Chaplin AJ. Splenic infarction and tissue accumulation of crystals associated with the use of clofazamine (Lamprene: B663) in the treatment of pyoderma gangrenosum. Br J Derm, 1980; 102: 227. 